\title{
ANALISIS YURIDIS KASUS PEMBOBOLAN REKENING PADA BANK MANDIRI
}

\section{ANALYSIS JURIDIS CASE OF ACCOUNTS HACKING IN MANDIRI BANK}

\section{Istiqlaliyah Tri Utami dan Muhammad Taufiq}

Program Studi Ilmu Hukum Sekolah Pascasarjana

Universitas Djuanda Bogor

Jl. Tol Ciawi No. 1, Kotak Pos 35, Bogor 16720.

Korespondensi : Istiqlaliyah Tri U, Telp. -

e-mail : istiqlalu@gmail.com

Jurnal Abstract : The identifications of this research are: 1) How did the customer's Living Law, Vol. 10, No. 1 , account break into the Depok Branch of Bank Mandiri ?; 2) What is the bank's responsibility towards the customer who is a victim of a Bank Mandiri Depok branch burglary? The research method used in this study is a normative juridical approach, namely law is conceived as a norm, rule, principle or dogmas / jurisprudence. The results of this study are: The form of corporate responsibility according to the law in an effort to provide protection for customers who have suffered losses on funds in their accounts can be done in non-litigation and litigation. Non-litigation reports to Indonesian banking mediation institutions, while litigation is through the court. Suggestions for this research, namely: 1) There needs to be a guarantee that means for customers who have entrusted their funds to banks; 2) The government must pay more attention to the activities of banks, especially for Bank Indonesia as a supervisor and supervisor of banking activities so that in this case the bank is more responsible.

Keywords : Account Hacking, Consumer Protection, Bank.

\begin{abstract}
Abstrak : Identifikasi penelitian ini yaitu: 1) Bagaimana terjadi pembobolan rekening nasabah pada Bank Mandiri Cabang Depok?; 2) Bagaimana tanggung jawab bank terhadap nasabah korban pembobolan rekening Bank Mandiri Cabang Depok? Metode penelitian yang digunakan dalam penelitian ini adalah pendekatan yuridis normatif, yaitu hukum dikonsepsikan sebagai norma, kaidah, asas atau dogma-dogma/yurisprudensi. Hasil dari penelitian ini yaitu: Bentuk pertanggungjawaban korporasi menurut undang-undang dalam upaya memberikan perlindungan bagi nasabah yang mengalami kerugian atas dibobol dana pada rekeningnya dapat dilakukan secara non litigasi dan secara litigasi. Secara non litigasi melakukan pelaporan kepada lembaga mediasi perbankan Indonesia, sedangkan secara litigasi melalui jalur pengadilan. Saran penelitian ini, yaitu: 1) Perlu adanya penjaminan yang berarti bagi nasabah yang telah mempercayakan dananya pada bank; 2) Pihak pemerintah agar lebih memperhatikan kegiatan dari bank-bank terutama bagi Bank Indonesia sebagai pembina dan pengawas terhadap kegiatan perbankan agar dalam hal ini pihak bank lebih bertanggung jawab.
\end{abstract}

Kata Kunci : Pembobolan Rekening, Perlindungan Konsumen, Bank 


\section{PENDAHULUAN}

Perkembangan ilmu pengetahuan dan teknologi atau yang kita kenal dengan istilah IPTEK, ditambah dengan perkembangan zaman atau yang kita kenal dengan istilah globalisasi tidak diragukan lagi telah membawa dampak yang sangat berarti terhadap perkembangan seluruh negara di dunia. Tidak terkecuali Indonesia sebagai salah satu negara yang sedang berkembang. Perkembangan yang terjadi tersebut mencakup segala bidang kehidupan bermasyarakat, berbangsa, dan bernegara yang salah satu di antaranya adalah bidang perekonomian. Dengan adanya perkembangan globalisasi ini telah sangat berpengaruh pada seluruh sistem perekonomian negara. Semakin banyak kegiatan ekonomi yang dilakukan suatu negara, tentu saja akan berbanding lurus dengan semakin cepatnya perputaran uang yang terjadi di dalamnya. Dengan adanya kondisi seperti ini, sektor riil tentu akan semakin bergerak maju atau semakin tumbuh dari waktu ke waktu.

Pada saat ini teknologi mengalami perkembangan di seluruh belahan dunia termasuk juga Indonesia. Salah satu perkembangan tersebut ditandai dengan munculnya internet hingga akhirnya tiba di suatu masa dimana penggunaan internet mulai menjadi sangat berperan di berbagai aspek kehidupan sehari-hari yang dikenal dengan teknologi berbasis internet (Internetbased technology). 1 Teknologi informasi telah menjadi fasilitas utama bagi kegiatan berbagai sektor kehidupan dimana memberikan andil besar terhadap perubahan-perubahan yang mendasar pada struktur operasi dan manajemen organisasi, pendidikan, kesehatan dan penelitian hingga di bidang perbankan. Peran teknologi di bidang perbankan sangat besar, karena kemajuan suatu sistem perbankan tidak dapat dipisahkan dengan peran teknologi informasi. ${ }^{2}$

\footnotetext{
1 Andi Hamzah, Hukum Pidana yang Berkaitan dengan Komputer, Jakarta: Sinar Grafika, 1993, Hlm. 122.

2 Ibid.
}

Produk-produk bank yang memanfaatkan perkembangan teknologi adalah: ${ }^{3}$

1. Anjungan Tunai Mandiri (Automated Teller Machine);

2. Sistem Aplikasi Perbankan (Banking Application System);

3. Sistem Penyelesaian Bruto WaktuNyata (Real-Time Gross Settlement System);

4. Perbankan Daring (Internet Banking); dan

5. Sistem Kliring Elektronik.

Penggunaan teknologi yang dimanfaatkan dalam produk-produk bank tersebut memberikan keuntungan tersendiri bagi bank, diantaranya adalah: ${ }^{4}$

\section{Business expansion}

Dahulu sebuah bank harus memiliki sebuah kantor cabang untuk beroperasi di tempat tertentu. Kemudian hal ini dipermudah dengan hanya meletakkan mesin ATM sehingga bank tersebut dapat beroperasi di tempat mesin ATM berada. Kemudian terdapat electronic banking ( $e$ banking) yang mulai menghilangkan batas fisik, menghilangkan batas ruang, dan waktu dimana nasabah dapat menggunakan media electronic untuk melakukan aktivitas perbankannya.

\section{Customer loyality}

Khususnya nasabah yang sering bergerak (mobile), akan merasa lebih nyaman untuk melakukan aktivitas perbankannya tanpa harus membuka account di bank yang berbeda-beda di berbagai tempat sehingga nasabah dapat menggunakan atau membuka account pada satu bank saja.

\section{Revenue and cost improvement}

Biaya untuk memberikan layanan perbankan melalui e-banking dapat lebih murah daripada membuka kantor cabang.

\section{Competitive advantage}

Bank yang memiliki fasilitas e-banking akan memiliki keuntungan dibandingkan dengan bank yang tidak memiliki $e$ banking. Dalam waktu dekat, orang tidak

\footnotetext{
${ }^{3}$ Ibid.

${ }^{4}$ Ibid., Hlm. 23.
} 
ingin membuka account di bank yang tidak memiliki fasilitas $e$-banking.

\section{New business model}

E-banking memungkinan adanya bisnis model yang baru. Layanan perbankan baru dapat diluncurkan melalui jaringan internet dengan cepat.

Semakin berkembang dan kompleks fasilitas yang diterapkan perbankan untuk memudahkan pelayanan, semakin beragam dan kompleks pula adopsi teknologi yang dimiliki oleh suatu bank. ${ }^{5}$ Setiap terdapat keuntungan dan kemudahan sudah tentu akan terdapat pula beberapa kelemahan dan kerugian yang didapatkan dari digunakannya teknologi yang ada. Kelemahan tersebut diantaranya adalah munculnya tindak kejahatan Informasi dan Transaksi Elektronik (ITE) atau cyber crime seperti kasus pembobolan terhadap sistem keamanan dan pembobolan rekening atau yang biasa disebut dengan hacking, sistem electronic nasabah dalam sistem perbankan nasional dengan menggunakan sarana prasarana dan identitas orang lain guna memalsukan kartu kredit dalam kejahatan yang disebut carding. ${ }^{6}$ Munculnya tindak kejahatan cyber crime di bidang perbankan sudah tentu akan menimbulkan kerugian bagi bank yang menjadi korban tindak kejahatan ITE di bidang perbankan yang dilakukan oleh pelaku kejahatan ITE di bidang perbankan.

Bank yang menjadi korban tersebut memiliki hak dalam mendapatkan hak-hak atas kerugian yang dialami dan juga perlindungan yang sama seperti nasabah bank. Kerugian tersebut baik menyangkut mengenai dengan sistem jaringan komputer yang dirusak atau dibobol oleh pelaku tindak kejahatan ITE di bidang perbankan juga ganti kerugian atas rekening nasabah yang telah dicuri atau dibobol oleh pelaku kejahatan ITE di bidang perbankan.

Sebagai contoh kasus dalam Putusan Pengadilan Negeri Depok Nomor 186/Pid.Sus/2012/PN.Dpk. Bahwa

\footnotetext{
5 Ibid.

${ }^{6}$ Ibid., Hlm. 121.
}

terdakwa Zurais Al-Korni Bin Hatib ${ }^{7}$ pada hari Jum'at tanggal 06 Januari 2012 sekitar pukul 11.41 wib atau pada hari yang sama sekitar pukul 21.48 wib bertempat di kampung jemblongan RT.01/11 No. 12 Kelurahan Pancoran Mas, Kecamatan Pancoran Mas, Kota Depok atau setidaktidaknya masih termasuk daerah hukum Pengadilan Negeri Depok, telah mengambil suatu barang berupa uang sejumlah Rp. 4.900.000,- (empat juta sembilan ratus ribu rupiah) dan Rp. 500.000,- (lima ratus ribu rupiah) milik saksi Oman, dengan sengaja dan tanpa hak atau melawan hukum mengakses komputer dan/atau sistem elektronik dengan cara apapun dengan melanggar, menerobos, melampaui atau menjebol sistem pengaman, perbuatan tersebut dilakukan secara berlanjut dengan cara mengakses internet banking pada komputer di rumahnya, lalu terdakwa membuka situs Bank Mandiri dengan mengetik di broser www.bankmandiri.co.id setelah masuk program Mandiri lalu terdakwa memasukkan no. user untuk mencari nama nasabah Bank Mandiri lewat internet banking Mandiri lalu terdakwa memilih nasabah perorangan, salah satu nasabah yang dipilih terdakwa bernama Oman dengan nomor rekening 1270004446207, kemudian terdakwa mengetik no. user id. Oman 123, setelah itu terdakwa mengetik password standar dengan nomor 123456, setelah terdakwa berhasil masuk kedalam situs banking mandiri Oman, lalu terdakwa mengecek saldo saksi Oman, setelah mengetahui jumlah uang dalam rekening Oman selanjutnya terdakwa mengetik layar transfer dan tampilan menu pilihan tabungan kemudian terdakwa mengklik layar transfer dan tampilan menu pilihan tabungan kemudian terdakwa memasukkan nomor rekening milik terdakwa yang berada di Bank BCA KCU Margonda Depok Pancoran atas nama Zurais Alkorni dengan nomor rekening 8690876133, lalu terdakwa mengetik

7 Putusan Pengadilan Negeri Depok Nomor 186/Pid.Sus/2012/PN.Dpk. 
nominal uang sebesar Rp. 4.900.000,(empat juta sembilan ratus ribu rupiah) yang akan ditransfer kedalam rekening Bank BCA milik terdakwa, setelah terdakwa mencantumkan jumlah uang sebesar Rp. 4.900.000,- (empat juta sembilan ratus ribu rupiah), lalu dari layar diperintahkan untuk memasukkan Nomor PIN kemudian terdakwa memasukkan Nomor PIN 111000, setelah terdakwa memasukkan PIN, kemudian terdakwa memasukkan nomor transfer lewat internet banking mandiri ke Bank BCA dinyatakan berhasil, dan setelah terdakwa berhasil menjebol Sistem Pengamanan Bank Mandiri dan berhasil mengambil uang sebesar Rp. 500.000,- (lima ratus ribu rupiah) dengan cara yang sama milik saksi Oman mendapat informasi dari SMS internet banking Bank Mandiri bahwa telah terjadi pendebitan pada tanggal 06 Januari 2012, karena tidak pernah melakukan transaksi di internet banking pada tanggal 06 Januari 2012 sebesar Rp. 4.900.000,(empat juta sembilan ratus ribu rupiah) dan Rp. 500.000,- (lima ratus ribu rupiah), lalu saksi Oman mengkomplain Bank Mandiri dan berdasarkan laporan komplainan saksi Oman maka pihak Bank Mandiri menindaklanjuti laporan tersebut dengan membentuk tim untuk mengungkap pelakunya dengan cara membuka lagi log transaksi internet banking Bank Mandiri nasabah Oman, maka kedua transaksi tersebut ditujukan ke rekening BCA atas nama Zurais Alkorni dengan nomor rekening 8690876133.

Selain bank yang menjadi korban dari tindak kejahatan ITE nasabah juga menjadi korban atas kejahatan yang dilakukan oleh pelaku kejahatan, akibat dari kejahatan ITE tersebut sudah selayaknya bank memberikan perlindungan terhadap nasabah dari berbagai kerugian yang akan muncul sesuai dengan ketentuan Pasal 2 Undang-undang Nomor 7 Tahun 1992 tentang Perbankan, sebagaimana telah dirubah dengan Undang-undang Nomor 10 Tahun 1998 tentang Perbankan, Pasal 37B ayat (1) yang berbunyi "Setiap bank wajib menjamin dana masyarakat yang disimpan pada bank yang bersangkutan."

Dalam melaksanakan tugasnya sebagai penghimpun dana dari masyarakat bank menganut asas kepercayaan dari masyarakat, apabila masyarakat percaya pada bank, maka masyarakat akan merasa aman untuk menyimpan uang atau dananya di bank dengan demikian, bank menanggung risiko reputasi atau reputation risk yang besar oleh karena itu sudah selayaknya bank memberikan perlindungan bagi nasabah yang menggunakan jasanya agar mendapatkan kepercayaan tersebut.

Dalam hal pemenuhan terhadap perlindungan nasabah telah terdapat Undang-undang yang menjamin tentang kepastian hukum bagi nasabah itu sendiri yaitu Undang-undang Nomor 8 Tahun 1999 tentang Perlindungan Konsumen, selanjutnya disebut dengan UUPK. Selain adanya pengaturan mengenai perlindungan nasabah juga telah terdapat beberapa pengaturan dasar mengenai tindak kejahatan e-banking di bidang perbankan yaitu Undang-undang Nomor 11 Tahun 2008 tentang Informasi dan Transaksi Elektronik, selanjutnya disebut dengan UU ITE.

Dalam penerapannya untuk menyelesaikan masalah dalam tindak kejahatan e-banking UU ITE memiliki kekurangan seperti apabila hakim menerapkan ketentuan UU ITE, maka hal tersebut hanya ditujukan kepada pelaku kejahatannya saja, sehingga UU ITE belum memberikan perlindungan atas hak-hak nasabah bank sebagai korban dari kejahatan ITE di bidang perbankan, sedangkan upaya hukum perdata yang dilakukan oleh pihak bank dan nasabah bank yang menjadi korban dari tindak kejahatan ITE di bidang perbankan, hakhak nasabah bank yang menjadi korban belum juga terealisasi. Berdasarkan realita yang ada lembaga perbankan tidak menjamin ganti kerugian material atas tindak kejahatan $e$-banking yang dilakukan oleh pelaku kejahatan ITE apabila tidak 
diatur secara terperinci dalam perjanjian penjaminan keamanan rekening antara pihak bank dan nasabah bank. ${ }^{8}$

Kejahatan secara umum dapat diartikan sebagai perbuatan yang dilakukan baik oleh perorangan maupun korporasi yang dapat merugikan orang lain maupun dirinya sendiri, kerugian tersebut dapat berupa kerugian jiwa, kesehatan, harta benda, kehormatan dan moral. Secara singkat kerugian yang diakibatkan dari kejahatan dapat berupa kerugian materiil dan/atau kerugian immateriil.

Kejahatan terjadi dihampir semua sektor kehidupan, termasuk sektor ekonomi. Salah satu kejahatan di sektor ekonomi adalah kejahatan bisnis, sedangkan salah satu kejahatan di dalam dunia bisnis adalah kejahatan perbankan. Hal ini didasarkan pada suatu pendapat ${ }^{9}$ yang menyatakan bahwa kejahatan bisnis yaitu kejahatan yang timbul dari praktik bisnis. Sedangkan bisnis itu merupakan salah satu aktivitas usaha yang utama dalam menunjang perkembangan ekonomi. Kata "bisnis" yang berarti kegiatan usaha. Istilah bisnis yang dimaksudkan adalah suatu urusan atau kegiatan dagang, industri atau keuangan yang dihubungkan dengan produksi atau pertukaran atau jasa, dengan menempatkan uang dari para entrepreneur dalam risiko tertentu dalam usaha tertentu dengan motif untuk mendapatkan keuntungan. Begitu juga dengan perbankan yang merupakan kegiatan usaha di bidang jasa yang tujuan utamanya mencari keuntungan. Jadi dapat disimpulkan bahwa "kejahatan perbankan merupakan kegiatan dari kejahatan bisnis".

Pengertian kejahatan perbankan di Indonesia antara lain dapat diketahui dari rumusan ketentuan Pasal 51 Undangundang Nomor 10 Tahun 1998 tentang

8 Kusuma Mahesa Jati, Hukum Perlindungan Nasabah Bank, Bandung; Nusa Media, 2012, Hlm. 11.

9 "Tinjauan Terhadap Kejahatan Perbankan", dikutip dari

https://erwan29680.wordpress.com/2009/03/30/ tinjauan-terhadapkejahatan-perbankan/, diakses pada tanggal 13 Mei 2017.
Perubahan atas Undang-undang Nomor 7 Tahun 1992 tentang Perbankan yang menyatakan bahwa "Tindak pidana sebagaimana dimaksud dalam Pasal 46, Pasal 47, Pasal 47A, Pasal 48 ayat (1), Pasal 49, Pasal 50 dan Pasal 50A adalah kejahatan". Jadi kejahatan perbankan adalah tindak pidana sebagaimana dirumuskan dalam Pasal 46, Pasal 47, Pasal 47A, Pasal 48 ayat (1), Pasal 49, Pasal 50 dan Pasal 50A Undang-undang Nomor 10 Tahun 1998 tentang Perbankan. Pada pokoknya dalam Undang-undang Perbankan tersebut telah menetapkan 13 (tiga belas) jenis kejahatan perbankan sebagaimana yang dirumuskan dalam Pasal 46 sampai dengan Pasal 50A. Ketiga belas kejahatan perbankan tersebut dapat digolongkan kedalam 4 (empat) macam kejahatan perbankan sebagai berikut:

1. Kejahatan yang berakitan dengan perizinan;

2. Kejahatan yang berkaitan dengan rahasia bank;

3. Kejahatan yang berkaitan dengan administrasi, pengawasan dan pembinaan;

4. Kejahatan yang berkaitan dengan usaha bank. $^{10}$

Dengan meningkatnya kejahatan di bidang perbankan, baik yang dilakukan oleh pengurus-pengurus bank, bankirbankir yang memanfaatkan bank yang dikelolanya dijadikan alat untuk memperkaya diri sendiri atau kepentingan diri sendiri sebagaimana contoh telah diuraikan sedikit di atas maupun sebagai jawaban atas meningkatnya risiko yang dihadapi oleh perbankan maka diperlukan suatu pengawasan dan pembinaan yang baik terhadap bank yang merupakan kewenangan Bank Indoensia (sekarang Otoritas Jasa Keuangan $=0 \mathrm{JK}$ ) dan juga peningkatan prinsip kehati-hatian oleh pihak bank sendiri di dalam menjalankan usahanya. ${ }^{11}$

Sehubungan dengan kejahatan perbankan Munir Fuady mengemukakan

${ }^{10}$ Ibid. 
bahwa kejahatan bank makin meningkat dewasa ini, modus operandinya pun makin canggih. Bahkan, dalam beberapa kasus, terlibat sindikat mafia, baik dari dalam maupun dari luar negeri. Di samping itu, lebih dari 90\% kejahatan bank dilakukan melalui kerja sama orang luar dan orang dalam bank. Uniknya, orang dalam tersebut terdiri dari para young urban profesional (Yuppies) Indonesia, dengan ciri-ciri yang sama: muda, pintar, gesit, workaholic, ambisius, punya posisi baik, punya penghasilan, dan memiliki angan-angan tinggi. Terkadang bahkan mereka menggunakan komputer sebagai sarana kejahatannya. Lalu populerlah apa yang sering disebut sebagai kejahatan komputer yang merupakan salah satu kristal dari kejahatan kerah putih (white collar crime). Di antara bentuk banking crimes adalah misaplikasi dari dana bank, false bank entries, laporan palsu kepada pemerintah, kredit palsu atau warkat palsu. Sayangnya tidak semua bentuk tersebut dapat diakomodasikan oleh hukum positif Indonesia saat ini. ${ }^{12}$

Jos Luhukay, pengamat Perbankan Strategi Indonesia, mengatakan, modus kejahatan perbankan bukan hanya soal penipuan (fraud), tetapi lemahnya pengawasan internal control bank terhadap sumber daya manusia juga menjadi titik celah kejahatan perbankan. "Internal control menjadi masalah utama perbankan. Bank Indonesia harus mengatur Standard Operating Procedure (SOP)".13

Otoritas Jasa Keuangan (OJK), lembaga pengawasan industri perbankan di Indonesia, sepanjang tahun 2016 menangani 619 kasus kejahatan perbankan di berbagai daerah. Investigator Eksekutif Departemen Pemeriksaan Khusus dan Investigasi Perbankan Otoritas Jasa

12 Munir Fuady, Hukum Bisnis Dalam Teori dan Praktik Buku Kesatu, Bandung: Citra Aditya Bakti, 1996, Hlm. 144.

13“"Inilah 9 Kasus Kejahatan Perbankan”, dikutip dari

http://bisniskeuangan.kompas.com/read/2011/05 /03/09441743/Inilah.9.Kasus.Kejahatan.Perbankan , diakses pada tanggal 13 Mei 2017.
Keuangan (OJK) Pusat, Beston Panjaitan, mengatakan dari jumlah kasus kejahatan perbankan tersebut, sebanyak 236 kasus telah divonis majelis hakim pengadilan.

Sedangkan sebanyak 146 kasus, telah dihentikan penyidikannya karena para tertuduh tidak diketahui lagi keberadaannya dan sebagian telah meninggal dunia. "Kita kesulitan menghadirkan para pelaku ke persidangan karena alamat tempat tinggalnya tidak diketahui lagi dan sebagian lagi sudah meninggal".14 Kemudian 10 kasus kejahatan perbankan lainnya, telah diserahkan kepada instansi lain untuk penyelesaiannya. Menurut Beston Panjaitan, kasus tindak pidana perbankan biasanya nasabah memberikan atau menitip ATM/buku tabungannya kepada orang lain atau pegawai bank. Akibatnya, pegawai yang memegang ATM atau buku tabungan dengan leluasa menguras uang nasabah yang ada di bank tempat menabung. "Untuk mencegah tindak kejahatan pihak pegawai bank, nasabah jangan pernah menitipkan ATM bersama PIN-nya kepada orang lain maupun pegawai bank". Sebab hal tersebut sama saja memberikan peluang kepada penerima titipan menyalahgunakan ATM pemilik dengan mencairkan uang tanpa sepengetahuan pemiliknya. ${ }^{15}$

Berdasarkan uraian latar belakang penelitian tersebut di atas maka peneliti dalam penelitian ini mengambil judul tentang: "ANALISIS YURIDIS KASUS PEMBOBOLAN REKENING BANK MANDIRI CABANG DEPOK".

Berdasarkan latar belakang penelitian di atas, maka penulis dapat mengidentifikasi masalah sebagai berikut:

1. Bagaimana terjadi pembobolan rekening nasabah pada Bank Mandiri Cabang Depok?

\footnotetext{
14“Ojk Tangani 619 Kasus Kejahatan Perbankan Sepanjang 2016", dikutip dari http://www.antaranews.com/berita/449592/ojktangani-619-kasuskejahatan-perbankan-sepanjang2013, diakses pada tanggal 13 Mei 2017.

15 Ibid.
} 
2. Bagaimana tanggung jawab bank terhadap nasabah korban pembobolan rekening Bank Mandiri Cabang Depok?

\section{METODE PENELITIAN}

Metode penelitian yang digunakan dalam penelitian ini adalah pendekatan yuridis normatif, yaitu hukum dikonsepsikan sebagai norma, kaidah, asas atau dogma-dogma/yurisprudensi. Tahap penelitian yuridis normatif, menggunakan studi kepustakaan (penelaahan terhadap literatur).

\section{PEMBAHASAN}

\section{A. PEMBOBOLAN REKENING NASABAH PADA BANK MANDIRI CABANG DEPOK}

Kejahatan pembobolan bank yang terjadi melibatkan para pihak di dalamnya, sebagian besar didukung oleh pihak terafiliasi atau pihak dalam bank itu sendiri yang paham prosedur dan sistem peredaran uang di bank tersebut termasuk sistem jaringan dan keamanan transaksi di bank tersebut. Pada saat melakukan kejahatan perbankan, pelaku biasanya menggunakan modus-modus operandi tertentu. Modus operandi mengandung makna cara melakukan kejahatan. Istilah modus operandi berbicara tentang bagaimana cara melakukan suatu tindak pidana atau tindak kejahatan. Dalam kaitan dengan persoalan modus operandi ini perlu dipahami bahwa bentuk-bentuk modus operandi yang dilakukan seorang pelaku dalam melakukan tindak kejahatannya sering kali istilahnya sama dengan istilah yang dipergunakan untuk tindakan yang dikualifikasikan sebagai delik menurut Kitab Undang-undang hukum Pidana (KUHP) atau peraturan perundangundangan lainnya. Kejahatan pembobolan bank termasuk dalam kelompok kejahatan kerah putih (white collar crime), ia merupakan bentuk kejahatan yang memerlukan intelektual dan teknologi yang canggih, sehingga hampir mustahil apabila ia dilakukan oleh orang yang tidak paham tentang bank. ${ }^{16}$

Modus operandi dalam pembobolan bank antara lain pemalsuan dokumen, transaksi fiktif, pembukuan ganda, manipulasi dan korupsi ${ }^{17}$, penggelapan uang nasabah, pemanfaatan/ penyalahgunaan prosedur seperti penyelewengan dalam transaksi yang menggunakan L/C, transfer, dan perubahan/perusakan data. ${ }^{18}$ Sebagian dari modus operansi tersebut dilakukan dengan menggunakan peralatan serta teknologi canggih berupa komputer, yakni dalam hal transfer dan perubahan/perusakan data.

Dari berbagai jabaran modus operandi yang dimungkinkan untuk dilakukan oleh pembobol bank, secara umum dapat dikelompokkan dalam 2 (dua) jenis kejahatan pembobolan bank, yaitu: 19

1. Kejahatan pembobolan bank dalam bentuk error omission

Bentuk error omission berupa pelanggaran terhadap suatu ketentuan berupa sistem dan prosedur yang seharusnya dipatuhi tetapi tidak dilaksanakan. Bagi pelanggarnya akan dikenakan sanksi administratif yang dimuat dalam ketentuan baku.

2. Kejahatan pembobolan bank dalam error commission

Berupa pelanggaran dalam bentuk melaksanakan sesuatu yang seharusnya tidak boleh, tetapi karena tidak tertulis dalam sistem dan prosedur tetap saja dilakukan. Bagi pelanggarnya akan dikenakan sanksi normatif yang biasanya dimuat dalam code of conduct (kode etik).

${ }^{16}$ Hermansyah, Op.Cit., Hlm. 149.

17 K. Wantjik Saleh, Tindak Pidana Korupsi dan Suap, Jakarta: Ghalia Indonesia, 1971, Hlm. 51.

18 Etrizal Suar, "Upaya Penanggulangan Pembobolan Bank", Tesis, Program Studi Ilmu Hukum Pascasarjana Universitas Indonesia: Jakarta, 1999, Hlm. 74.

19 Krisna Wijaya, Kejahatan Perbankan dalam Perbankan Nasional Catatan Kolom Demi Kolom, Cetakan Kedua, Jakarta: PT. Kompas Media Nusantara, 2002, Hlm. 38. 
Pembobolan bank yang dilakukan oleh pelaku pada umumnya menggunakan kecanggihan teknologi komputer dan pengetahuan tentang seluk beluk transaksi dalam dunia perbankan. Hal ini lah yang memungkinkan kontribusi pihak dalam (pihak terafiliasi) dalam kejahatan ini begitu besar. Berikut ini akan dipaparkan modus operandi yang digunakan oleh pelaku dalam melakukan pembobolan bank, yang terdiri dari:

\section{Pemalsuan Dokumen}

Bentuk pemalsuan yang dilakukan dalam pembobolan bank merupakan pemalsuan dokumen-dokumen perbankan. Pada saat nasabah penyimpan dana akan melakukan transaksi perbankan, terlebih dahulu ia harus memenuhi kelengkapan administratif sebagai bagian dari prosedur yang berlaku di dalam transaksi perbankan, dengan kesempatan inilah para pelaku pembobolan bank mengambil peluang untuk melakukan aksinya dengan memalsukan surat-surat yang diperlukan tersebut. Jika surat-surat palsu (yang memang dipalsukan oleh pelaku kejahatan) yang ternyata oleh pihak bank surat-surat tersebut dianggap asli, secara administratif akan dapat dilakukan transaksi perbankan antara pihak bank dengan nasabah. Pada saat transaksi itu berlangsung pihak bank belum mengetahui keberadaan pemalsuan surat-surat atau dokumen-dokumen yang merupakan prasyarat transaksi yang dilakukannya. Pemalsuan dokumendokumen tersebut dapat berupa:

a) Pemalsuan sertifikat deposito.

b) Melakukan transaksi palsu/transaksi fiktif (transfer atau mutasi-mutasi fiktif, penghapusan kredit (write off) fiktif, pencairan kredit fiktif dan sebagainya.

c) Pemalsuan warkat-warkat, seperti pemalsuan sertifikat tanah, buku pemilikan kendaraan bermotor, faktur, lembar bilyet giro, lembar cek, dll.

d) Pemalsuan kartu kredit.
Bentuk pemalsuan dokumen-dokumen perbankan ini, pada umumnya dilakukan oleh pihak internal bank atau pihak terafiliasi khususnya karyawan atau pengurus bank yang merupakan orang yang dengan mudah memiliki peluang untuk melakukan kecurangan tersebut disamping juga ia mengetahui prosedur dan kelemahan dari aktivitas transaksi perbankan yang menggunakan dokumendokumen.

Kasus yang terjadi pada Bank Mandiri Cabang Depok melakukan pembobolan bank senilai Rp. 5.400.000,- (Lima juta empat ratus ribu rupiah) oleh terdakwa Zurais Al-Korni Bin Hatib pada hari Jum'at tanggal 06 Januari 2012 sekitar pukul 11.41 WIB atau pada hari yang sama sekitar pukul 21.48 wib bertempat di Kampung Jemblongan RT.01/11 No. 12 Kelurahan Pancoran Mas, Kecamatan Pancoran Mas, Kota Depok milik saksi Oman.

\section{Pembukuan Ganda}

Modus operandi dengan menggunakan pembukuan ganda, pada umumnya dilakukan dengan cara menerbitkan laporan pembukuan ganda, yang satu asli dan yang satu lagi adalah fiktif. Pembukuan ganda ini digunakan oleh pihak dalam bank yang melakukan manipulasi atau korupsi pada bank bersangkutan, hal ini dilakukan untuk menutupi kondisi keuangan bank yang pada umumnya mengalami defisit akibat dari tindakan pejabat atau pegawai bank yang mengambil keuntungan secara curang, disamping itu juga untuk menghindari pembekuan operasi oleh Bank Indonesia.

\section{Penggelapan Uang Nasabah}

Modus operandi pembobolan bank dengan menggelapkan uang nasabah dilakukan dengan cara memanfaatkan kondisi rekening nasabah yang rajin melakukan transaksi penyimpanan dana tetapi jarang bahkan hampir tidak pernah melakukan penarikan dana.

4. Mekanisme Transfer Dana 
Mekanisme transfer dana terbagi atas dua, yaitu: (1) menggunakan sistem transfer dana secara internal dalam satu bank, (2) menggunakan sistem transfer dana yang melibatkan bank pengirim dan penerima yang berbeda (antar bank). Pembobolan bank melalui mekanisme transfer dana terjadi karena adanya keterlibatan orang dalam bank. Pelaksanaannya dapat terjadi dengan memanfaatkan teknologi.

5. Pemanfaatan/Penyalahgunaan

Prosedur Mekanisme L/C

Selain dengan menggunakan kelemahan mekanisme transfer, kejahatan pembobolan bank yang sering dilakukan adalah dengan menggunakan dokumen kredit atau yang lebih dikenal dengan Letter of Credit (L/C). ${ }^{20}$

Pada dasarnya, fasilitas L/C disediakan melalui produk perbankan bidang ekspor impor, baik fasilitas yang diberikan sebelum realisasi ekspor (pre-shipment finance) ${ }^{21}$ maupun fasilitas yang diberikan setelah realisasi (post-shipment finance) ${ }^{22}$. Pemberian fasilitas prapengapalan atau fasilitas kredit ekspor berlaku layaknya seperti pemberian kredit modal kerja, konsumsi, atau investasi. Berdasarkan asumsi bahwa ekspor atau pengapalan barang ke luar negeri belum terjadi maka L/C tidak bisa menjadi jaminan kredit, namun $\mathrm{L} / \mathrm{C}$ sudah menjadi dasar pengajuan kredit ekspor. Sementara itu, untuk status L/C pascapengapalan yang dibuktikan dengan kehadiran dokumen, akan menjadi acuan bank devisa untuk menentukan kebijaksanaan menolak atau memberikan fasilitas wesel ekspor. Selama bank diberikan wewenang oleh $\mathrm{L} / \mathrm{C}$ untuk menegosiasi dan dokumen ekspornya

\footnotetext{
${ }^{20}$ Hermansyah, Op.Cit., Hlm. 94.

21 Fasilitas pre-shipment finance diberikan guna pembayaran proses produksi untuk tujuan ekspor dengan menunjukkan L/C yang diterima pengekspor dari luar negeri.

22 Fasilitas post-shipment finance disediakan dalam bentuk negosiasi wesel ekspor dari L/C atas unjuk (sight L/C) dan diskonto wesel ekspor dari $\mathrm{L} / \mathrm{C}$ berjangka (usance $\mathrm{L} / \mathrm{C}$ ) .
}

sesuai dengan syarat dan kondisi L/C (comply with) maka bank prinsipnya sudah bisa memutuskan untuk memberikan fasilitas. ${ }^{23}$ Pada prinsipnya, sejak menerbitkan $\mathrm{L} / \mathrm{C}$, issuing bank telah terikat membayar maksimum senilai nominal $\mathrm{L} / \mathrm{C}$. Namun, issuing bank baru efektif bertanggung jawab atas pembayaran $\mathrm{L} / \mathrm{C}$ bila ada tagihan dari pengekspor berdasarkan dokumen yang diserahkan dengan kondisi comply with. ${ }^{24}$

Jaminan pembayaran oleh issuing bank karena kondisi dokumen yang comply with menjadi dasar kebijaksanaan negotiating bank untuk memberikan fasilitas negosiasi wesel ekspor. Sementara fasilitas diskonto wesel ekspor hanya bisa diberikan kepada pengekspor apabila ada bukti akseptasi (kesanggupan bayar oleh pengimpor pada tanggal tertentu) dari issuing bank. Di samping akseptasi itu, penting untuk menjadi pegangan negotiating bank, juga ketentuan tanggal sanggup bayar di kemudian hari yang tercantum pada saat sanggup (akseptasi) akan menjadi dasar perhitungan bunga di muka (diskonto) sejak tanggal fasilitas itu dikucurkan. L/C diterbitkan karena akan dilakukan transaksi ekspor-impor antara pengekspor dengan pengimpor dengan cara pembayaran yang melibatkan bank. L/C ini pun akan menjadi jaminan pengekspor untuk memastikan pembayaran dari issuing bank sebagai antisipasi apabila muncul ketidakmampuan pengimpor dalam melaksanakan pembayarannya. ${ }^{25}$

L/C Akan menjadi masalah apabila sengaja diterbitkan untuk mengelabui issuing bank dan negotiating bank sehingga L/C benar-benar diterbitkan tanpa kecurigaan bank sedikit pun. Mula-mula pengimpor dan pengekspor bersepakat

23 FR. Sumarwan, "Mewaspadai Pembobolan Bank Melaluui Transaksi L/C", Hukum Bisnis, Volume 24-No. 1 Tahun 2005, Hlm. 28-29.

24 Tok Suwarto, "Bisnis Kriminal Pembobolan Bank Nasional", <http://www.pikiranrakyat. com/cetak/1206/15.htm>, Diakses pada tanggal 10 Oktober 2017.

${ }^{25}$ FR. Sumarwan, Loc.Cit. 
membagi tugas seolah-olah akan ada jual beli barang lintas negara (ekspor fiktif). Melalui sales contract yang dibuat, pengimpor datang ke issuing bank untuk mengajukan aplikasi pembukaan $\mathrm{L} / \mathrm{C}$. Singkat kata, L/C yang sudah diterbitkan langsung dikirim kepada pengekspor melalui bank yang ditunjuk dalam L/C sebagai negotiating bank. Berdasarkan L/C yang diterimanya, pengekspor dapat mengajukan fasilitas kredit ekspor. Untuk selanjutnya, apabila waktu proses produksi, pengepakan dan pengiriman barang ekspor dipandang cukup rasional, pengekspor dapat mempersiapkan dokumen seolah-olah ada realisasi ekspor guna memperoleh fasilitas wesel ekspor. Setelah bank memberikan fasilitas negosiasi wesel ekspor, bank meneruskan dokumen ke issuing bank untuk menagih pembayaran. Tagihan atas dokumen pertama langsung dibayarkan oleh pengimpor melalui issuing bank sehingga pelunasan atas tagihan wesel ekspor pada negotiating bank dapat diselesaikan. Semakin cepat respons pengimpor untuk membayar dokumen, semakin meningkat kepercayaan issuing bank kepada pengimpor dan pada gilirannya negotiating bank juga akan lebih tertarik untuk memberikan fasilitas ekspor kepada pengekspor. Kalau sudah mendapatkan kepercayaan dari kedua bank tersebut, pengimpor dan pengekspor yang memang sejak mulanya tidak memiliki itikad baik akan memainkan jurus-jurus jitu yang tidak akan tampak dalam jangka pendek. ${ }^{26}$

Persoalannya adalah bank belum tentu menyadari akan permainan pengekspor dalam memanipulasi fasilitas bank. Bisa saja pengekspor mulai membobol dana bank pada saat terima kredit ekspor secara berulang-ulang. Sementara itu, banknya sendiri tidak merasa dirugikan karena tagihan kredit ekspornya dilunasi dengan fasilitas wesel ekspor. Mungkin juga

\footnotetext{
26 F.R. Sumarwan, "Ketika Musim Pembobolan Bank Tiba", <http://www.pikiranrakyat.com/cetak/1206/10/0 801.htm>, Diakses pada tanggal 10 Oktober 2017.
}

pengimpor luar negeri pada awal-awal transaksinya membayar tagihan dokumen atau membayar tepat waktu sesuai tanggal jatuh tempo, sedangkan fasilitas wesel ekspornya dilunasi dari hasil pembayaran pengimpor luar negeri. Modus operandi pembobolan dana bank melalui L/C tidak mudah terdeteksi karena bank sama sekali tidak berurusan dengan transaksi barang. Itu persoalan yang tidak pernah dipahami secara lebih dalam.

Sementara itu, kebenaran realisasi pengiriman barang ekspor hanya dibuktikan dengan kehadiran dokumen ekspor. Sekalinya ada pemalsuan dokumen ekspor, tentu akan sulit menanganinya. Kejahatan pembobolan bank yang banyak terjadi sebagian besar melibatkan pihak interen bank (pihak terafiliasi) yang mengetahui dan memahami tentang seluk beluk perbankan. Tindakan curang tersebut tentunya memiliki dampak yang dapat merugikan baik secara mikro maupun secara makro. Pembobolan bank yang dilakukan dengan modus operandi apa pun kesemuanya sama-sama menggunakan atau memanfaatkan kecanggihan teknologi yang ada. Dampak negatif secara mikro yang dapat ditimbulkan sebagai akibat dari kejahatan pembobolan bank terjadi pada nasabah perbankan itu sendiri. Sebagian nasabah yang dirugikan secara individu oleh pelaku pembobolan bank dapat meminta pertanggungjawaban bank agar simpanannya dapat dikembalikan kedalam kondisi semula, pada kenyataannya apabila nasabah tersebut mengklaim, ia harus dapat menunjukkan bukti-bukti nyata bahwa ia telah dirugikan atas tindakan pelaku pembobolan bank yang curang, prosedurnya pun mengalami proses yang panjang.

\section{B. TANGGUNG JAWAB BANK TERHADAP NASABAH KORBAN PEMBOBOLAN REKENING BANK MANDIRI CABANG DEPOK}


Pelanggaran hak nasabah oleh bank dapat diselesaikan melalui jalur hukum. Namun ketika kita kembali sadarkan terhadap nilai-nilai Negara hukum Pancasila dan Undang-Undang Dasar 1945 yang mengedepankan asas musyawarah, forum mediasi merupakan dimensi yang juga penting. ${ }^{27}$

Artinya, ketika sengketa perbankan masih dapat diselesaikan secara baik dan tetap menguntungkan kedua belak pihak, maka jalur hukum atau pengadilan dapat dikesampingkan/dihentikan. Hal ini juga terkait dengan prinsip penyelesaian sengketa secara murah, sederhana dan cepat.

Hadirnya upaya tersebut tentu tidak terlepas dari hubungan timbal balik antara nasabah dan bank, baik itu nasabah penyimpan dalam bentuk tabungan maupun deposito atau nasabah lain. Hubungan timbal balik ini dapat berupa pemberian bunga oleh pihak bank terhadap simpanan dari nasabah, serta kewajibankewajiban nasabah untuk memenuhi ketentuan sistem administrasi tertentu apabila hendak mengambil atau menyimpan uang.

Selain itu sebagai upaya peningkatan dan pemberdayaan nasabah, tentu bank sebagai pelaku usaha harus memberikan layanan penyelesaian dan infrastruktur atas berbagai keluhan dan pengaduan nasabah. Media penyelesaian ini juga harus memenuhi standar waktu dan pelayanan, Artinya dapat berlaku secara efektif dan efesien.

Bank Indonesia sebagai pemegang otoritas perbankan Indonesia dalam upaya memenuhi standar tersebut juga telah memprioritaskan program-program terkait perlindungan nasabah, termasuk penanganan pengaduan nasabah, termasuk penanganan perbankanan pembentukan lembaga mediasi perbankan independen.

27 Az. Lukman Santoso, Hak dan Kewajiban Hukum Nasabah Bank, Yogyakarta: Pustaka Yustisia, 2011, Hlm. 126.
Dalam ranah hukum, seorang tentu harus bertanggung jawab terhadap kerugian yang diakibatkan oleh perbuatan yang bertentangan dengan hukum dari orang lain, hal ini disebut tanggung jawab kwalitatif, yaitu orang yang bertanggung jawab karena orang itu memiliki suatu kwalitas tertentu.

Sesuai dengan penerapan hukum di Indonesia, seorang konsumen yang dilakukan oleh pelaku usaha, termasuk nasabah kepada bank, dapat menggugat pihak yang menimbulkan kerugian atas produk dan jasanya tersebut. Kwalifikasi gugatan yang lazim adalah wanprestasi atau perbuatan melawan hukum.

Dalam gugatan adanya wanprestasi, maka terdapat hubungan kontraktual antara konsumen dan pelaku usaha/produsen. Kerugian yang dialami oleh nasabah tidak lain adalah karena tidak dilaksanakan prestasi oleh bank sebagai pelaku usaha.

Apabila tidak terdapat hubungan kontraktual antara nasabah dan bank, maka tidak ada tanggung jawab (hukum) pelaku usaha nasabah. Hal inilah yang dikenal dengan doktrin yang mengandung prinsip "tidak ada hubungan kontraktual, tidak ada tanggung jawab".

Sedangkan dalam gugatan berdasarkan perbuatan melawan hukum, hubungan kontraktual tidaklah disyaratkan. Dalam hal ini nasabah haruslah membuktikan adanya unsur-unsur:28

1. Adanya perbuatan melawan hukum,

2. Adanya kesalahan/kelalaian pelaku usaha,

3. Adanya kerugian yang dialami oleh konsumen,

4. Adanya hubungan kausal antara perbuatan melawan hukum dan kerugian yang dialami oleh konsumen.

Pada Undang-Undang Nomor 8 Tahun 1999 tentang Perlindungan Konsumen, dalam konteks pertanggungjawaban pelaku

${ }^{28}$ Ibid., Hlm. 127. 
usaha atas gugatan nasabah ini, diatur beberapa ketentuan: ${ }^{29}$

\section{Pertanggungjawaban Pidana Korporasi}

Subjek hukum tindak pidana UndangUndang Perlindungan Konsumen adalah pelaku usaha. Pelaku usaha yang termasuk dalam pengertian ini adalah perusahaan, korporasi, BUMN, koperasi, impotir, pedagang, distributor, dan lain-lain. Artinya, bank pemerintah maupun swasta, termasuk Bank Perkreditan termasuk kategori ini.

\section{Hak Gugat Lembaga Konsumen}

Lembaga konsumen, atas nama kepentingan konsumen, dapat mengajukan gugatan atas pelanggaran yang dapat dilakukan pelaku usaha yang merugikan kepentingan konsumen (Pasal 46 ayat (1) huruf c UUPK). Disini lembaga konsumen mempunyai hak gugat (legal standing to sue) kepada pelaku usaha, lepas ada atau tidak ada surat kuasa dari konsumen yang dirugikan.

\section{Gugatan Kepentingan Kelompok}

Terhadap sengketa konsumen yang melibatkan konsumen dalam jumlah besar/missal, padahal ini persoalaan menyangkut hal yang sama, konsumen dapat mengajukan gugatan kepentingan kelompok (class action) kepada pelaku usaha (Pasal 46 ayat (1) huruf b UUPK).

\section{Beban Pembuktian Terbalik}

Pelaku usaha bertanggung jawab memberikan ganti rugi atas kerusakan, pencemaran, dan/atau kerugian konsumen akibat menggunakan produk atau jasa yang dihasilkan atau diperdagangkan (Pasal 19 ayat (1) UUPK).

Ganti rugi dapat berupa pengembalian uang atau penggantian barang dan/atau jasa yang sejenis atau setara nilainya, atau perawatan kesehatan dan/atau pemberian santunan yang sesuai dengan ketentuan peraturan Perundang-undangan yang berlaku. ${ }^{30}$

\footnotetext{
29 Ibid.

${ }^{30}$ Ibid., Hlm. 128.
}

Ketentuan ini tidak berlaku apabila pelaku usaha dapat membuktikan bahwa kerugian tersebut merupakan atau sebagai akibat kesalahan konsumen. Sehingga, pembuktian terhadap ada tidaknya unsur kesalahan dalam gugatan- gugatan ganti rugi, merupakan beban dan tanggung jawab pelaku usaha (Pasal 28 UUPK).

Pada umumnya nasabah akan mengalami kesulitan untuk membuktikan unsur ada tidaknya kesalahan atau kelalaian pelaku usaha. Untuk itulah dianut doktrin productliability, dimana tergugat dianggap telah bermasalah (presumption of guilty) kecuali ia mampu membuktikan bahwa ia tidak melakukan kelalaian atau kesalahan. Maka ia harus memikul resiko kerugian yang dialami pihak lain karena mengkonsumsi atau menggunakan produknya.

Peraturan Bank Indonesia Nomor 5/8/PBI/2003 tentang Penerapan Manajemen Risiko Bagi Bank Umum (selanjutnya disingkat PBI No.5/8/ PBI/2003). Perlunya manajemen resiko ini ada kaitannya dengan kepercayaan masyarakat terhadap dunia perbankan, sehingga perlu menghindari potensi terjadinya suatu peristiwa (events) yang dapat menimbulkan kerugian bank. ${ }^{31}$

Sedangkan mengenai manajemen resiko merupakan serangkaian prosedur dan metodologi yang digunakan untuk mengidentifikasi, mengukur, memantau, dan mengendalikan resiko yang timbul dari kegiatan usaha bank. Perihal manajemen resiko, bank wajib menerapkan Manajemen Resiko secara efektif.

Penerapan Manajemen Resiko sebagaimana dimaksud dalam ayat (1) sekurang-kurangnya mencakup:

a. Pengawasan aktif dewan Komisaris dan Direksi;

b. Kecukupan kebijakan, prosedur, dan penetapan limit;

31 Muhammad Djumhana, Hukum Perbankan Di Indonesia, Bandung: Citra Aditya Bakti, 2000, Hlm. 370- 371 . 
c. Kecukupan proses identifikasi, pengukuran, pemantauan dan pengendalian resiko serta sistem informasi Manajemen Resiko; dan

d. Sistem pengendalian intern yang menyeluruh sebagaimana Pasal 2 PBI No. 5/8/PBI/2003.

Resiko perbankan tersebut menurut Pasal 4 PBI No. 5/8/PBI/2003 meliputi:

(1) Resiko sebagaimana dimaksud dalam Pasal 2 mencakup:

a. Risiko Kredit;

b. Resiko Pasar;

c. Risiko Likuiditas;

d. Resiko Operasional;

e. Resiko Hukum;

f. Resiko Reputasi;

g. Resiko Strategik;

h. Resiko Kepatuhan.

(2) Bank yang memiliki ukuran dan kompleksitas usaha yang tinggi wajib menerapkan Manajemen Resiko sebagaimana dimaksud dalam Pasal 2 ayat (2) untuk seluruh jenis risiko sebagaimana dimaksud dalam ayat (1).

Mengenai pihak yang berwenang dan bertanggung jawab atas resiko yang terjadi adalah Komisaris dan Direksi. Menurut Pasal 6 PBI No.5/8/PBI/2003 menentukan sebagai berikut:

Wewenang dan tanggung jawab bagi dewan Komisaris sekurangkurangnya:

a. Menyetujui dan mengevaluasi kebijakan Manajemen Resiko;

b. Mengevaluasi pertanggungjawaban Direksi atas pelaksanaan kebijakan Manajemen Resiko sebagaimana dimaksud dalam huruf a;

c. Mengevaluasi dan memutuskan permohonan Direksi yang berkaitan dengan transaksi yang memerlukan persetujuan dewan Komisaris.

Sedangkan kewenangan dan Tanggung Jawab Direksi diatur dalam Pasal 7 PBI No. 5/8/PBI/2003 yang menentukan:

(1) Wewenang dan tanggung jawab sebagaimana dimaksud dalam Pasal 5 bagi Direksi sekurang-kurangnya: a. Menyusun kebijakan dan strategi Manajemen Resiko secara tertulis dan komprehensif;

b. Bertanggung jawab atas pelaksanaan kebijakan Manajemen Resiko dan eksposur Resiko yang diambil oleh Bank secara keseluruhan;

c. Mengevaluasi dan memutuskan transaksi yang memerlukan persetujuan Direksi;

d. Mengembangkan budaya Manajemen Resiko pada seluruh jenjang organisasi;

e. Memastikan peningkatan kompetensi sumberdaya manusia yang terkait dengan Manajemen Resiko;

f. Memastikan bahwa fungsi Manajemen Resiko telah beroperasi secara independen;

g. Melaksanakan kaji ulang secara berkala untuk memastikan:

1) Keakuratan metodologi penilaian Resiko;

2) Kecukupan implementasi sistem informasi manajemen; dan

3) Ketepatan kebijakan, prosedur dan penetapan limit Resiko.

(2) Dalam rangka melaksanakan wewenang dan tanggung jawab sebagaimana dimaksud dalam ayat (1), Direksi harus memiliki pemahaman yang memadai mengenai Resiko yang melekat pada seluruh aktivitas fungsional bank dan mampu mengambil tindakan yang diperlukan sesuai dengan profil risiko. ${ }^{32}$

Bank merupakan simbol kepercayaan masyarakat terhadap kondisi moneter suatu Negara. Begitu besarnya kepercayaan masyarakat terhadap bank, sehingga sebuah bank menderita "sakit" sedikit saja, pengaruhnya cukup terasa bagi sendi-sendi ekonomi Negara, peran otoritas moneter, seperti Bank Indonesia, mutlak diperlukan guna mengawasi tingkat kesehatan suatu

\footnotetext{
32 Ibid., Hlm. 371.
} 
bank. ${ }^{33}$ Bank Indonesia merupakan Bank Sentral yang ada di Indonesia, ia merupakan lembaga negara yang mempunyai wewenang untuk mengeluarkan alat pembayaran yang sah dari suatu negara, merumuskan dan melaksanakan kebijakan moneter, mengatur dan menjaga kelancaran sistem pembayaran, mengatur dan mengawasi perbankan, serta menjalankan fungsi sebagai leader of last resort. ${ }^{34}$

Undang-undang yang kini berlaku mengatur kedudukan Bank Indonesia sebagai Bank Sentral yaitu Undang-Undang Nomor 3 Tahun 2004 tentang Bank Indonesia sebagai perubahan atas UndangUndang Nomor 23 Tahun 1999 tentang Bank Indonesia. Bank Indonesia berkedudukan serta berkantor pusat di Ibu Kota Negara (Jakarta) serta dapat mempunyai kantor-kantor di dalam dan di luar wilayah Negara Republik Indonesia. Adapun penamaan kantor di dalam negeri disebut kantor cabang sedangkan kantor di luar negeri disebut kantor perwakilan. Pada kantor-kantor tersebut dapat dilakukan kegiatan Bank Indonesia sesuai dengan tugas dan wewenangnya.

Bank Indonesia dalam kedudukannya sebagai badan hukum (publik) yaitu sebagai lembaga Negara selain mempunyai wewenang dalam mengelola kekayaan sendiri yang terlepas dari Anggaran Pendapatan dan Belanja Negara (APBN) juga berwenang untuk menetapkan peraturan dan mengenakan sanksi dalam batas kewenangannya. ${ }^{35}$ Dengan kedudukannya sebagai lembaga Negara, Bank Indonesia merupakan lembaga independent yang bidang tugasnya berada di luar pemerintahan dan lembaga lain kecuali yang telah tegas diatur dalam

33 Yusuf, Sofie, Perlindungan Konsumen dan Instrumen-instrumen Hukumnya, Bandung: Citra Aditya Bakti, 2003, Hlm. 41.

34 Muhammad Djumhana, Op.Cit., HIm. 93.

35 Gunarto Suhardi, Risiko Kriminalisasi Kredit Perbankan, Cetakan Pertama, Andi Offset: Yogyakarta, 2006, Hlm. 19.
Undang-Undang Nomor 3 Tahun 2004 tentang Bank Indonesia.

Kemandirian Bank Indonesia menyebabkan pihak lain dilarang untuk melakukan segala bentuk campur tangan terhadap pelaksanaan tugas Bank Indonesia, namun sebaliknya Bank Indonesia wajib pula menolak dan/atau mengabaikan segala bentuk campur tangan dari pihak manapun. Namun dalam kemandiriannya tersebut Bank Indonesia tetap wajib menyampaikan laporan pelaksanaan tugasnya kepada Dewan Perwakilan Rakyat (DPR), sedangkan laporan keuangannya diperiksa oleh Badan Pemeriksa Keuangan (BPK).

Konsekuensi sebagai lembaga yang bertujuan untuk menjaga dan memelihara kestabilan nilai rupiah, maka Bank Indonesia mempunyai tugas sebagaimana yang terdapat dalam Pasal 8 UndangUndang Bank Indonesia, yaitu untuk:

1. Menetapkan dan melaksanakan kebijakan moneter;

2. Mengatur dan menjaga kelancaran sistem pembayaran;

3. Mengatur dan mengawasi bank.

Dalam rangka mendukung tugas tersebut di atas Bank Indonesia dapat menyelenggarakan survei berupa pengumpulan informasi yang bersifat makro atau mikro seperti survey mengenai kegiatan usaha, survey konsumen, survey perkembangan harga asset, dan surveysurvey lainnya seperti survey dalam rangka penyusunan dan penyempurnaan statistik neraca pembayaran.

Sesuai dengan ketentuan Pasal 64 Undang-Undang Nomor 3 Tahun 2004 tentang Bank Indonesia, Bank Indonesia selain mempunyai tugas utamanya juga dapat melakukan penyertaan modal pada badan hukum atau badan lainnya yang sangat diperlukan dalam pelaksanaan tugas Bank Indonesia, yaitu diantaranya: lembaga kliring, badan pemeringkat, dan lembaga penjamin simpanan. Penyertaan modal ini hanya dapat dilakukan dengan persetujuan Dewan Perwakilan Rakyat. 
Adapun dana untuk penyertaan modal tersebut hanya dapat diambil dari dana cadangan tujuan.

\section{Pengawasan Eksternal Yang Dilakukan Oleh Bank Indonesia}

Pengawasan eksternal yang dilakukan oleh Bank Indonesia meliputi empat kewenangan, yaitu:

a. Power to Regulate

Sistem hukum suatu Negara dapat mempengaruhi kondisi perekonomian suatu Negara. Krisis ekonomi yang terjadi dipenghujung tahun 1997 menyebabkan pemerintah, lembaga keuangan internasional dan pengamat lainnya telah berusaha untuk memahami penyebab dari krisis regional tersebut, dan mereka berkesimpulan bahwa sistem hukum dari Negara yang terkena krisis merupakan salah satu faktor yang memberikan kontribusi. $^{36}$ Masalah terpuruknya perbankan, selain menyangkut masalah pemilik, pengelola dan pengawas bank, juga menyangkut penegakan hukum dan seluruh perangkat kelembagaannya, dari ketentuan perundangan sampai ke lembaga penegak hukum. ${ }^{37}$

\section{b. Power to Lisence}

Perketat mekanisme pendirian bank dalam hal persyaratan pendirian bank. Kewenangan pemberian izin ini merupakan seleksi awal terhadap berdirinya sebuah bank. Sebelum menjalankan usahanya, suatu bank harus lebih dahulu mendapat izin dari Bank Indonesia untuk mendapatkan izin sebagai bank, bank terlebih dahulu harus melalui dua tahapan berikut, yaitu: ${ }^{38}$

1) Mendapatkan izin prinsip yang mencakup 3 (tiga) aspek, yaitu: 1) akhlak dan moral calon pemilik dan pengurus bank, 2) kemampuan menyediakan dana dalam jumlah tertentu atau modal bank, dan 3) kesungguhan dan kemampuan dari

${ }^{36}$ Zulkarnain Sitompul, Op.Cit., Hlm. 250.

37 J. Soedradjad Djiwandono, Bergulat Dengan Krisis dan Pemulihan Ekonomi Indonesia, Jakarta: Pustaka Sinar Harapan, 2001, Hlm. 69.

${ }^{38}$ Hermansyah, Op.Cit., Hlm. 31. para calon pemilik dan pengurus bank dalam melakukan kegiatan usaha bank.

2) Mendapatkan izin usaha, yang lebih kepada syarat administratif pendirian suatu bank. Izin usaha baru dapat diberikan apabila izin prinsip telah dipenuhi.

\section{c. Power to Control}

Kewenangan untuk mengendalikan atau mengawasi merupakan kewenangan yang paling mendasar yang diperlukan oleh otoritas pengawas bank. Adapun kontrol yang dilakukan oleh lembaga independent dalam hal menjaga kesehatan bank. Pengawasan bank dilaksanakan melalui pengawasan tidak langsung (off site supervision), yaitu pengawasan yang dilakukan melalui alat pantau seperti laporan berkala yang disampaikan bank, laporan hasil pemeriksaan dan informasi lainnya. Dengan data yang diperoleh melalui alat pantau tersebut, otoritas pengawas melakukan penilaian terhadap keadaan usaha dan kesehatan bank. Selain pengawasan tidak langsung ada juga pengawasan langsung (on site examination) yang dapat berupa pemeriksaan umum dan pemeriksaan khusus. Pengawasan langsung ini bertujuan untuk memperoleh gambaran tentang ketaatan terhadap peraturan yang berlaku serta untuk mengetahui apakah terdapat praktik-praktik yang tidak sehat yang membahayakan kelangsungan usaha bank. ${ }^{39}$

\section{d. Power to Impose Sanction}

Liberalisasi industri perbankan harus diikuti dengan penerapan prinsip tata kelola perusahaan yang baik. Untuk menerapkan prinsip itu hukum harus diterapkan dengan tegas. Sanksi optimal harus diterapkan kepada siapa saja yang mencoba bermain-main dengan ketentuan yang diberlakukan. Faktor budaya hukum yang merupakan salah satu persyaratan bekerjanya sistem hukum sangat lemah di Negara-negara berkembang. Oleh karena itu, regulator harus tegas agar terbentuk

\footnotetext{
${ }^{39}$ Ibid., Hlm. 167.
} 
budaya hukum sebagai penyeimbang dilaksanakannya liberalisasi.

Setiap individu yang terbukti melakukan kecurangan (fraud) harus dihukum berat. Apabila bank melakukan pelanggaran ketentuan perbankan, maka tidak hanya bank sebagai perusahaan yang dikenai denda karena seringkali pengurus tidak begitu perduli kalau hanya bank yang didenda, seharusnya pengurus sebagai pribadi juga dikenakan sanksi denda oleh pengawas dan apabila pelanggaran sudah memasuki wilayah kriminal, maka para pelaku tersebut tidak hanya dipenjarakan tetapi juga seluruh harta kekayaannya dirampas untuk Negara. Dukungan pengadilan juga dibutuhkan agar langkahlangkah yang diambil oleh regulator tidak dimentahkan oleh pengadilan. Agar pengawas dapat bertindak tegas, perlu dipertimbangkan untuk memberikan kewenangan yang lebih besar kepada mereka.

Dalam rangka menjalankan tugasnya untuk mengatur dan mengawasi bank, Bank Indonesia berdasarkan Peraturan Bank Indonesia No. 8/5/PBI/2006, 30 Januari 2006 tentang Mediasi Perbankan, dapat menawarkan penyelesaian sengketa antara nasabah dengan bank yang disebabkan tidak terpenuhinya tuntutan finansial nasabah oleh bank (Pasal 2), yang akan melaksanakan tugas melakukan mediasi perbankan akan diberikan lembaga khusus yaitu Lembaga mediasi perbankan independen yang nantinya akan didirikan berdasarkan Pasal 3 Peraturan bank Indonesia paling lambat 31 Desember 2007, sebelum terbentuknya lembaga mediasi perbankan independen, maka fungsi mediasi perbankan dilakukan oleh Bank Indonesia. Fungsi mediasi yang dilaksanakan oleh Bank Indonesia terbatas pada upaya membantu nasabah dan bank untuk mengkaji ulang sengketa secara mendasar dalam rangka memperoleh kesepakatan (Pasal 14).

\section{Pengawasan Internal Oleh Manajemen Bank}

Pengawasan secara internal dapat dilakukan dengan upaya melakukan penyehatan manajemen perbankan dengan memperbaiki aspek manajemen personalia, moralita dan mentalitas para banker yang merupakan titik sentral yang perlu mendapatkan penekanan kearah pertumbuhan dan perkembanagn bank secara sehat. Untuk itu Bank Indoneisa mengeluarkan aturan bersih diri 40 bagi mereka yang ingin mengelola bank, baik banker maupun pemilik. Pengawasan secara internal meliputi: ${ }^{41}$

\section{a. Penerapan Tata Kelola Perusahaan}

Lemahnya penerapan tata kelola perusahaan menyebabkan kejahatan perbankan sering terjadi. Penerapan tata kelola dimaksudkan untuk memberikan peranan yang lebih besar kepada pasar agar dapat bekerja lebih efisien dan mengurangi tanggung jawab pemerintah kepada masyarakat. Meningkatkan peran pasar dan mengurangi peran pemerintah merupakan suatu cara pertumbuhan ekonomi. Menciptakan pasar yang efisien berarti mengurangi atau menurunkan "kontrol" bukan meningkatkan kontrol untuk meminimalkan akses pasar. Lemahnya sistem tata kelola perusahaan memberikan kesempatan kepada pengurus untuk memperkaya diri sendiri atas tanggungan pemegang saham.

\section{b. Prinsip Know Your Employee}

Bank tidak saja harus mengenali nasabahnya sesuai dengan prinsip know your customer dengan maksud agar bank tidak digunakan oleh nasabahnya sebagai tempat untuk menyembunyikan hasil kejahatan seperti menyimpan uang hasil korupsi. Hal yang tidak kalah pentingnya adalah penerapan prinsip know your employee yaitu kenali karyawan anda. Berbagai kasus pembobolan bank yang

40 Eko Budi Supriyanto, Skandal Demi Skandal Mulai Meledakkan Bank Infobank, Edisi Khusus, Juni, Nomor 211/1997.

41 Zulkarnain Sitompul, "Memberantas Kejahatan Perbankan: Tantangan Pengawasan Bank" , Hukum Bisnis, Volume 24-No.1-Tahun 2005, Hlm. 13. 
melibatkan karyawan bank mengajarkan bagaimana karyawan bank merampok bank tempat yang bersangkutan bekerja. Untuk itu manajemen harus secara seksama memperhatikan pola tindak karyawannya dan usaha yang lebih penting dilakukan adalah dengan berusaha menciptakan sumber daya manusia yang integritasnya tinggi, ${ }^{42}$ sehingga penyimpangan yang dilakukan karyawan dapat didektesi secara dini.

\section{c. Peningkatan Peran Kepatuhan (Compliance Unit)}

Internal auditor seharusnya mampu mendeteksi kejahatan perbankan yang melibatkan orang dalam dan kemudian mendiskusikannya dengan manajemen masalah yang sedang dihadapi dan langkah-langkah yang diperlukan untuk memperbaikinya. Peran unit kepatuhan harus dimaksimalkan. Untuk itu, sepuluh prinsip yang diterbitkan oleh basel committee on banking supervision untuk mengefektifkan fungsi unit kepatuhan pada bank harus diterapkan oleh pengurus bank.

3. Pengawasan Oleh Masyarakat

Pengawasan oleh masyarakat dilakukan dengan menerapkan prinsip keterbukaan (transparansi). Bukti yang tersedia mengungkapkan bahwa pasar memberikan peringatan dini yang sangat baik tentang adanya bank bermasalah. Ada beberapa studi yang mendukung pandangan ini. Studi yang dilakukan oleh Petty dan Sinkey terhadap 6 (enam) bank yang bangkrut menemukan bahwa sinyal pasar terjadi pada rata-rata 33 (tiga puluh tiga) minggu sebelum lembaga pengawas mencantumkan bank tersebut pada daftar bank bermasalah. ${ }^{43}$ Alasan lain perlunya industri perbankan lebih transparan adalah peningkatan kompleksitas bisnis perbankan. Kondisi ini harus diikuti oleh peningkatan keterbukaan tentang praktik

\footnotetext{
42 Krisna Wijaya, Teori dan Praktek Keuangan Mikro di Indonesia, Yogyakarta: Sekolah Pascasarjana Universitas Gadjah Mada, 2010, HIm. 42.

${ }^{43}$ Zulkarnain Sitompul, Op.Cit. HIm. 257.
}

manajeman risiko, bentuk risiko dan kinerja manajeman risiko yang dibarengi dengan keterbukaan mengenai permodalan sehingga dapat memfasilitasi disiplin pasar. Keterbukaan yang tepat waktu mengenai informasi tersebut memungkinkan pengawas dan peserta pasar melakukan penilaian yang lebih sempurna tentang bagaimana suatu bank memelihara kesehatannya.

Tiga ukuran dapat dipergunakan untuk menilai tingkat kesehatan bank oleh masyarakat, yaitu: 44

1. Apabila bank secara de fakto tidak memiliki akses ke pasar antar bank, atau memiliki akses namun dengan tingkat bunga yang tinggi. Informasi ini secara normal tidak dipublikasikan, tetapi secara adil harus tersedia untuk masyarakat. Informasi mengenai suku bunga yang ditawarkan untuk deposito juga dapat dipergunakan sebagai ukuran.

2. Perbedaan antara suku bunga deposito yang ditawarkan antara bank yang satu dengan bank yang lain. Suku bunga yang jauh lebih tinggi merupakan indikasi bahwa bank tersebut sedang kesulitan likuidasi.

3. Hadiah yang ditawarkan oleh suatu bank. Dengan tingkat kemampuan bank menyalurkan kredit yang rendah seperti saat ini (loan to deposito ratio), maka apabila ada bank yang menawarkan hadiah "wah" bagi deposan tentunya perlu dipertanyakan.

Dalam kaitannya dengan penerapan prinsip keterbukaan ini perlu pula dipertimbangkan agar sanksi yang dijatuhkan kepada suatu bank karena tidak patuh kepada peraturan perundangan diumumkan kepada masyarakat. Pengumuman ini penting agar masyarakat mengetahui bank-bank yang tidak patuh.

\section{Basle Committee on Banking} Supervision telah mengidentifikasikan 6 (enam) kategori informasi untuk

\footnotetext{
44 Ibid, Hlm. 57.
} 
membantu pencapaian tingkat keterbukaan bank yang memuaskan, yaitu: 45

a. Kinerja keuangan.

b. Posisi keuangan (termasuk pemodalan, solvensi dan likuidasi).

c. Praktik dan strategi manajemen risiko.

d. Risk exposure (termasuk risiko kredit, risiko pasar, risiko likuidasi, dan risiko operasional, hukum dan lainnya).

e. Kebijaksanaan akuntansi.

f. Bisnis dasar, informasi pengaturan (governance) perusahaan dan manajemen.

Lembaga swadaya yang merupakan perwakilan dari masyarakat umum dapat memberikan pengawasan terhadap kinerja bank. Salah satu lembaga swadaya yang dapat berperan disini adalah Yayasan Lembaga Konsumen Indonesia (YLKI), yang dapat melakukan upaya perlindungan hukum bagi konsumen nasabah penyimpan dana pada suatu bank atas perilaku curang dari bank atau pelaku kejahatan pembobolan bank atas dasar permintaan dari nasabah penyimpan dana yang dirugikan atau dengan inisiatif sendiri dari YLKI tersebut, melalui opini-opini yang dapat memberikan informasi secara benar dan jelas kepada masyarakat umum khususnya konsumen bank penyimpan dana. Melalui informasi yang benar dan jelas masyarakat akan dapat mengambil tindakan-tindakan untuk menyelamatkan asset yang dia punya pada bank yang bermasalah secara mandiri, sehingga tidak akan membuat susah pemerintah.

Penyelesaian

permasalahan pembobolan bank dapat dilakukan dengan cara melaporkan kepada Lembaga Mediasi Perbankan Indonesia yang berkantor di Bank Indonesia selaku Bank Central yang dapat memberikan pengawasan terhadap kinerja perbankan. Apabila persoalan kejahatan pembobolan bank ini dirasa belum dapat diselesaikan oleh Lembaga Mediasi Perbankan atau telah diselesaikan

45 Ibid, Hlm. 258. tetapi hasil yang diperoleh belum cukup adil bagi pihak yang dirugikan, maka upaya hukum lain yang dapat ditempuh adalah dengan mekanisme proses melalui pengadilan.

\section{KESIMPULAN}

Berdasarkan hasil penelitian dan pembahasan di atas, penulis dapat mengambil kesimpulan sebagai berikut:

Bank Indonesia sebagai pemegang otoritas perbankan Indonesia dalam upaya memenuhi standar yang berlaku dalam bidang perbankan telah memprioritaskan program terkait terhadap perlindungan nasabah, penanganan pengaduan nasabah, dan termasuk penanganan pembentukan lembaga mediasi perbankan yang independen. Perlunya manajemen resiko ini sebagai bentuk yang ada kaitannya dengan kepercayaan masyarakat terhadap dunia perbankan, sehingga perlu menghindari potensi terjadinya suatu peristiwa (events) yang dapat menimbulkan kerugian bank. Bentuk pertanggungjawaban korporasi menurut undang-undang dalam upaya memberikan perlindungan bagi nasabah yang mengalami kerugian atas dibobol dana pada rekeningnya dapat dilakukan secara non litigasi dan secara litigasi. Secara non litigasi melakukan pelaporan kepada lembaga mediasi perbankan Indonesia, sedangkan secara litigasi melalui jalur pengadilan.

\section{SARAN}

1. Perlu adanya penjaminan yang berarti bagi nasabah yang telah mempercayakan dananya pada bank, jaminan dari pemerintah melalui Lembaga Penjamin Simpanan memang telah ada hanya saja batas maksimal dana yang dijamin oleh bank hanya maksimal dua Milyar Rupiah, bagaimana nasib nasabah yang dananya melebih jaminan tersebut. Belum lagi dana yang dijamin hanya 
dana dalam bentuk tabungan, Giro dan Deposito saja, sedangkan dalam bentuk lain seperti danareksa itu tidak dijamin keberadaannya. Pemerintah harusnya tidak memberikan batasan jaminan, tetapi memberikan jaminan penuh atas dana nasabah dalam bentuk apapun.

2. Pihak pemerintah agar lebih memperhatikan kegiatan dari bankbank terutama bagi Bank Indonesia sebagai pembina dan pengawas terhadap kegiatan perbankan agar dalam hal ini pihak bank lebih bertanggung jawab dan memperhatikan apa yang menjadi hakhak dari pihak nasabah dan apabila bank-bank pelaksana melalaikan kewajiban dan tanggung jawab maka perlu ada sanksi yang tegas terhadap bank tersebut.

\section{UCAPAN TERIMA KASIH}

\section{DAFTAR PUSTAKA}

\section{Buku:}

Andi Hamzah, Hukum Pidana yang Berkaitan dengan Komputer, Jakarta: Sinar Grafika, 1993.

Az. Lukman Santoso, Hak dan Kewajiban Hukum Nasabah Bank, Yogyakarta: Pustaka Yustisia, 2011.

Gunarto Suhardi, Risiko Kriminalisasi Kredit Perbankan, Cetakan Pertama, Andi Offset: Yogyakarta, 2006.

J. Soedradjad Djiwandono, Bergulat Dengan Krisis dan Pemulihan Ekonomi Indonesia, Jakarta: Pustaka Sinar Harapan, 2001.

K. Wantjik Saleh, Tindak Pidana Korupsi dan Suap, Jakarta: Ghalia Indonesia, 1971.

Krisna Wijaya, Kejahatan Perbankan dalam Perbankan Nasional Catatan Kolom Demi Kolom, Cetakan Kedua, Jakarta: PT. Kompas Media Nusantara, 2002.

---------, Teori dan Praktek Keuangan Mikro di Indonesia, Yogyakarta: Sekolah Pascasarjana Universitas Gadjah Mada, 2010.

Kusuma Mahesa Jati, Hukum Perlindungan Nasabah Bank, Bandung; Nusa Media, 2012.

Muhammad Djumhana, Hukum Perbankan Di Indonesia, Bandung: Citra Aditya Bakti, 2000.

Munir Fuady, Hukum Bisnis Dalam Teori dan Praktik Buku Kesatu, Bandung: Citra Aditya Bakti, 1996, Hlm. 144.

Yusuf, Sofie, Perlindungan Konsumen dan Instrumen-instrumen Hukumnya, Bandung: Citra Aditya Bakti, 2003.

\section{Peraturan Perundang-undangan}

Undang-undang Dasar Negara Republik Indonesia Tahun 1945. 
Undang-undang Nomor 10 Tahun 1998 Tentang Perubahan Atas Undang-undang Nomor 7 Tahun 1992 tentang Perbankan.

Undang-undang Nomor 11 Tahun 2008 tentang Informasi dan Transaksi Elektronik.

Undang-undang Nomor 8 Tahun 1999 tentang Perlindungan Konsumen.

Putusan Pengadilan Negeri Depok Nomor 186/Pid.Sus/2012/PN.Dpk.

\section{Jurnal, Tesis}

Eko Budi Supriyanto, Skandal Demi Skandal Mulai Meledakkan Bank Infobank, Edisi Khusus, Juni, Nomor 211/1997.

Etrizal Suar, "Upaya Penanggulangan Pembobolan Bank”, Tesis, Program Studi Ilmu Hukum Pascasarjana Universitas Indonesia: Jakarta, 1999.

FR. Sumarwan, "Mewaspadai Pembobolan Bank Melaluui Transaksi L/C", Hukum Bisnis, Volume 24-No. 1 Tahun 2005.

Zulkarnain Sitompul, "Memberantas Kejahatan Perbankan: Tantangan Pengawasan Bank", Hukum Bisnis, Volume 24-No.1-Tahun 2005.

\section{Internet}

"Inilah 9 Kasus Kejahatan Perbankan", dikutip dari http://bisniskeuangan.kompas.com/read/2011/05/03/09441743/Inilah.9.Kasus.K ejahatan.Perbankan, diakses pada tanggal 13 Mei 2017.

“Ojk Tangani 619 Kasus Kejahatan Perbankan Sepanjang 2016”, dikutip dari http://www.antaranews.com/berita/449592/ojk-tangani-619-kasuskejahatanperbankan-sepanjang-2013, diakses pada tanggal 13 Mei 2017.

"Tinjauan Terhadap Kejahatan Perbankan", dikutip dari https://erwan29680.wordpress.com/2009/03/30/tinjauan-terhadapkejahatanperbankan/, diakses pada tanggal 13 Mei 2017.

F.R. Sumarwan, "Ketika Musim Pembobolan Bank Tiba", <http://www.pikiranrakyat.com/cetak/1206/10/0801.htm>, Diakses pada tanggal 10 Oktober 2017.

Tok Suwarto, "Bisnis Kriminal Pembobolan Bank Nasional", <http://www.pikiranrakyat. com/cetak/1206/15.htm>, Diakses pada tanggal 10 Oktober 2017. 